Riwayat Artikel: Diterima 20 Juni 2017; Direvisi 17 Juli 2017; Disetujui 18 Juli 2017; dan Dipublikasikan 26 Juli 2017

\title{
AKTIVITAS PENGGUNAAN PORTAL TELKOM SEBAGAI MEDIA KOMUNIKASI INTERNAL TERHADAP PEMENUHAN KEBUTUHAN INFORMASI KARYAWAN PT. TELKOM DCS REGIONAL SEMARANG
}

\author{
ACTIVITIES OF USAGE TELKOM PORTAL AS INTERNAL \\ COMMUNICATION TOWARD INFORMATION NEED AMONG \\ EMPLOYEES OF PT TELKOM DCS REGIONAL SEMARANG
}

\author{
Annisa Febiastu Sasongko \\ (febysasongko@gmail.com) \\ (Magister Ilmu Komunikasi, FISIP, UNDIP)
}

\begin{abstract}
Abstrak
Portal Telkom merupakan media komunikasi internal perusahaan dengan format virtual internet yang menjadi sarana serta wadah segala informasi tentang perusahaan bagi karyawan PT. Telkom DCS Regional Semarang. Permasalahan dalam penelitian ini adalah apakah ada hubungan antara aktivitas penggunaan portal Telkom sebagai media internal perusahaan terhadap terpenuhinya kebutuhan informasi mengenai perusahaan di kalangan karyawan dan apakah ada hubungan antara interaksi sosial dengan pemenuhan kebutuhan informasi karyawan. Hasil penelitian menunjukkan aktivitas penggunaan portal Telkom sebagai media internal perusahaan termasuk dalam kategori tinggi (51.30\%) yang berarti lebih dari setengah responden memanfaatkan portal Telkom sebagai sumber informasi untuk memenuhi kebutuhan informasi perusahaan baik di pusat maupun kantor cabang. Sementara tingkat pemenuhan kebutuhan informasi karyawan juga termasuk dalam kategori tinggi dengan prosentase $55.13 \%$ yang menunjukkan mengakses portal Telkom dapat memenuhi kebutuhan informasi, dan pengaruh interaksi di lingkungan kerja berada pada kategori tinggi (66.67\%) membuktikan bahwa melalui interaksi sosial para karyawan dapat menambah tingkat pemenuhan kebutuhan informasi akan perusahaan.
\end{abstract}

Kata Kunci: Media Komunikasi, Komunikasi Internal, Kebutuhan Informasi Karyawan

\begin{abstract}
The major functions of Telkom Portal as an electronic communication tool are to providing and serving information through a virtual format technology system for the employees. The study attempts to identify the relationship between employee activities of using Telkom Portal as an internal communication medium to the fulfillment of corporate information needs and interest. It also assesses employee social cognitive elements and social interaction at the work place. The results shows that Telkom portal usage activity as internal media is included in high category (51.30\%) which means more than half of respondents utilize Telkom portal as information source to fulfill information requirement of company either in center or branch office. While the level of fulfillment of employee information needs is also included in the high category with the percentage of $55.13 \%$ indicating accessing Telkom portal can meet the information needs. And the influence of interaction in the work environment is in the high category (66.67\%) proves that through social interaction the employees can increase the level of fulfillment of information needs of the company.
\end{abstract}

Keywords: Communication Media, Internal Communication, Employee Information Need

\section{Pendahuluan}

PT. Telkom tidak saja berupaya membangun teknologi komunikasi dan informasi bagi masyarakat Indonesia, tetapi juga berusaha mengaplikasikan kemajuan teknologi komunikasi dan informasinya pada internal perusahaannya

sendiri. Yang menjadi lingkup internal perusahaan diantaranya adalah employee public (publik pegawai), manager public (publik manajer), stock holder public (publik pemegang saham) dan labour public (publik buruh). Didalam 
perusahaan, pemilihan saluran serta media pengiriman pesan komunikasi merupakan faktor yang harus diperhatikan, karena akan berpengaruh pada tingkat efektivitas penyampaian pesan.

Efektivitas komunikasi melalui media komunikasi tercermin dari kemampuan media tersebut untuk mempengaruhi kelompok sasaran sesuai dengan yang diinginkan. Pada awalnya PT. Telkom menggunakan format majalah (yang bernama majalah KOIN) sebagai media internal perusahaannya namun seiring berjalannya waktu dan dengan berbagai macam pertimbangan, tim manajemen kemudian mencari cara untuk menyampaikan berbagai macam pesan melalui cara yang lebih efektif dan efisien melalui penggunaan teknologi internet. Penggunaan media internal melaui media internet dirasa lebih unggul dibandingkan penggunaan media internal melalui media cetak (majalah). Adanya komunikasi bermedia komputer akan memperlancar penanggulangan hambatan-hambatan dikarenakan adanya hambatan-hambatan karena batasan ruang dan waktu. Jadi lokasi pegawai secara fisik sudah tidak relevan lagi. Dengan memanfaatkan tekhnologi baru bermedia komputer ini, para pegawai dapat berhubungan dengan siapapun dan dimanapun dalam organisasi (Pace dan Faules, 2002: 229).

Sebagai media internal perusahaan, Portal Intranet Telkom berfungsi sebagai sarana komunikasi, informasi, pendidikan, hiburan serta pengetahuan bagi publik internal. Management web portal Intranet Telkom juga membuka kesempatan bagi karyawan yang berminat untuk menyumbangkan berbagai artikel atau informasi. Dengan demikian, aliran informasi tidak hanya bersifat horizontal tetapi juga vertikal (sejajar) antar karyawan, hal ini menunjukan bahwa informasi mengenai perusahaan tidak hanya dimonopoli oleh pihak manajemen, karena selain menerima informasi karyawan juga dapat memberikan informasi. Adanya interaksi yang harmonis antara para karyawan dalam suatu organisasi, baik dalam hubungannya secara timbal balik maupun secara horizontal diantara para karyawan secara timbal balik pula di sebabkan oleh adanya komunikasi (Effendy, 2002: 116).

Keberadaan Web Portal Intranet Telkom diharapkan mampu memenuhi kebutuhan informasi serta menambah pengetahuan karyawan akan segala berita perkembangan yang ada di perusahaan. Sementara berbagai fasilitas link yang ada didalam portal diharapkan dapat menciptakan hubungan yang baik antara perusahaan dengan karyawan maupun karyawan dengan karyawan perusahaan.

Berdasarkan latar belakang yang telah dikemukakan di atas, maka perumusan masalah dalam penelitian ini adalah: (1) apakah ada hubungan yang signifikan antara aktivitas penggunaan Portal Telkom sebagai media internal perusahaan dengan pemenuhan kebutuhan informasi karyawan PT. Telkom DCS Regional Semarang?; (2) apakah ada hubungan yang signifikan antara lingkungan kerja dengan pemenuhan kebutuhan informasi karyawan PT. Telkom DCS Regional Semarang?

Adapun tujuan dari penelitian ini, yaitu: (1) untuk mengetahui apakah ada hubungan yang signifikan antara aktivitas penggunaan Portal Telkom sebagai Media Internal Perusahaan dengan pemenuhan kebutuhan informasi karyawan PT. Telkom DCS Regional Semarang; (2) untuk mengetahui apakah ada hubungan yang signifikan antara interaksi di lingkungan kerja dengan pemenuhan kebutuhan informasi karyawan PT. Telkom DCS Regional Semarang.

\section{Metodologi}

Penelitian ini menggunakan metode penelitian survey (kuantitatif) dengan populasi atau unit analisis yang akan diteliti yaitu seluruh karyawan PT. Telkom DCS Regional IV Semarang yang 
berjumlah 78 orang. Teknik pengambilan sampel dalam penelitian ini adalah total sampling atau sensus. Total sampling atau sensus adalah teknik pengambilan sampel di mana semua anggota populasi digunakan sebagai sampel karena jumlah populasinya kurang dari 100 (Sugiyono, 2009: 124).

\section{Hasil dan Pembahasan}

Berdasarkan pengolahan data dan uji statistik yang telah dilakukan pada bab sebelumnya dengan menggunakan korelasi Tata Jenjang Spearman, maka ditemukan hasil penelitian sebagai berikut: (1) aktivitas penggunaan portal Telkom sebagai Media Internal Perusahaan kepada karyawan PT. Telkom DCS Regional Semarang termasuk dalam kategori tinggi, yaitu sebesar $51.30 \%$. Hal ini berarti lebih dari setengah responden memanfaatkan portal Telkom sebagai sumber informasi untuk memenuhi kebutuhan informasi mereka mengenai perusahaan. Hal ini dapat dikarenakan Portal Telkom menjadi wadah segala informasi perusahaan baik di pusat maupun kantor cabang; (2) tingkat pemenuhan kebutuhan informasi karyawan PT. Telkom DCS Regional Semarang juga termasuk dalam kategori tinggi dengan prosentase sebesar 55,13\%. Hal ini membuktikan bahwa melalui mengakses portal Telkom responden dapat memenuhi kebutuhan informasi mereka seputar halhal yang berkaitan dengan perusahaan; dan (3) pengaruh interaksi di lingkungan kerja pada karyawan berada pada kategori tinggi yaitu sebesar $66,67 \%$. Hal ini membuktikan bahwa melalui interaksi sosial para karyawan PT. Telkom DCS Regional Semarang dapat menambah tingkat pemenuhan kebutuhan informasi karyawan akan perusahaan.

Dalam penelitian ini bidang komunikasi serta teori yang dianggap relevan diantaranya adalah komunikasi organisasi yang menyangkut media internal perusahaan, motivasi penggunaan media dan pemenuhan kebutuhan informasi karyawan serta menggunakan teori uses and gratifications.

PT. Telekomunikasi Indonesia (Telkom) yang memiliki banyak kantor cabang di seluruh Indonesia. Tentu tidak mudah untuk menyatukan visi dan misi perusahaan yang memiliki jumlah karyawan yang begitu besar. Maka dari itu PT. Telkom berusaha untuk mengoptimalkan fungsi PR yang ada serta membuat kebijakan untuk menyediakan media internal sebagai wadah penyampaian pesan dan informasi.Media komunikasi internal adalah semua sarana penyampaian dan penerimaan informasi dikalangan publik internal perusahaan dan biasanya bersifat non komersial. Baik penerima maupun pengirim informasi adalah orang dalam ataupun publik internal yang terdiri atas pimpinan, anggota, pegawai ataupun unit-unit kerja didalam perusahaan tersebut (A. W. Suranto, 2005:121).

Sementara itu, ada dua jenis media internal, yakni yang semata-mata bersifat internal (khusus untuk para staf dan pegawai) dan yang sampai batas tertentu bersifat eksternal (yang juga diarahkan kepada pihak luar tertentu). Publikasi atau terbitan yang didistribusikan kepada para anggota atau pun khalayak pendukung dari suatu organisasi lazim disebut sebagai media internal semi eksternal.

Keberadaan Public Relations timbul karena adanya tuntutan kebutuhan. Di dalam suatu perusahaan Public Relations mempunyai tujuan untuk memberikan kepuasan terhadap semua pihak yang berkepentingan, baik pihak internal maupun eksternal.

Portal Telkom merupakan web internal perusahaan berbasis tekhnologi intranet. Menurut Keneth C. Laudon (2005: 410), intranet adalah jaringan organisasi internal yang bisa memberikan akses data di lintas perusahaan. Sementara menurut Sutedjo (2003: 92), intranet adalah sistim jaringan yang hanya bisa digunakan untuk keperluan internal dan 
hanya bisa diakses oleh anggota organisasi. Biasanya hanya bisa digunakan untuk saling mengirimkan dan menerima informasi dan laporan antar karyawan ". Dengan demikian Intranet adalah sistim jaringan komunikasi yang hanya bisa diakses dalam internal perusahaan. Jaringan ini bersifat seperti internet, yang memungkinkan kita melakukan komunikasi interaktif dan akses data internal perusahaan.

Intranet merupakan media yang interaktif. Interaktif disini adanya hubungan timbal balik antara satu pengguna dengan pengguna lain sekalipun tidak secara langsung. Intranet adalah jaringan komputer dalam perusahaan yang menggunakan komunikasi data standar seperti dalam internet. Artinya kita dapat menggunakan semua fasilitas internet untuk apapun kebutuhan perusahaan (Tung, 2001: 4).

Pada dasarnya 'motif' dan 'motivasi' artinya hampir sama, hanya berbeda pada penempatan kalimat saja. Motivasi adalah sebab, alasan dasar, pikiran dasar, dorongan bagi seseorang untuk berbuat atau ide pokok yang selalu berpengaruh besar terhadap tingkah laku manusia. Dengan kata lain, motivasi adalah dorongan terhadap seseorang agar mau melaksanakan sesuatu. Dorongan adalah desakan alami untuk memuaskan kebutuhan-kebutuhan hidup. Dari definisi tersebut, motif jika dihubungkan dengan konsumsi media berarti segala alasan dan pendorong dalam diri manusia yang menyebabkan seseorang menggunakan media.

Bila dikaitkan dengan lingkungan yang merangsang timbulnya kebutuhan, khususnya yang berhubungan dengan seseorang yag dihadapkan pada berbagai media penampung informasi, maka ada banyak kebutuhan yang bisa dikemukakan, antara lain sebagai berikut: (1) kebutuhan kognitif: hal ini berkaitan erat dengan kebutuhan untuk memperkuat informasi, pengetahuan dan pemahaman seseorang akan lingkungannya. Kebutuhan ini didasarkan pada hasrat seseorang untuk memahami dan menguasai lingkungannya. Di samping itu, kebutuhan ini juga dapat memberi kepuasan atas hasrat keingintahuan dan penyelidikan seseorang; (2) kebutuhan afektif: kebutuhan ini dikaitkan dengan penguatan estetis, hal yang dapat menyenangkan dan pengalamnpengalaman emosional. Dalam hal ini, berbagai media dalam hal ini sering dijadikan alat untuk mengejar kesenangan dan hiburan. Misalnya, orang membeli radio, televisi dan menonton film, tidak lain karena mencari hiburan; (3) kebutuhan integrasi personal (personal integrative needs), ini dikaitkan dengan penguatan kredibilitas, kepercayaan, stabilitas dan status individu. Kebutuhan - kebutuhan ini berasal dari hasrat seseorang untuk mencari harga diri; (4) kebutuhan integrasi sosial (social integrative needs): kebutuhan ini dikaitkan dengan penguatan hubungan keluarga, teman dan orang lain di dunia. Kebutuhan ini didasari oleh hasrat seseorang untuk bergabung atau berkelompok dengan orang lain; (5) kebutuhan berkhayal (escapist needs), ini dikaitkan dengan kebutuhan - kebutuhan untuk melarikan diri, melepaskan ketegangan dan juga hasrat untuk mencari hiburan maupun mencari pengalihan (Yusup, 2009: 207).

Media Portal Telkom bertujuan untuk memenuhi kebutuhan atas informasi perusahaan bagi karyawan. Kebutuhan informasi menurut Atkin didefinisikan sebagai berikut: 'kebutuhan informasi adalah fungsi dari keraguan ekstrinsik yang dihasilkan dari suatu perbedaan pengamatan antara kriteria ukuran kepastian seseorang mengenai objek lingkungan yang penting dan pernyataan terhadap suatu kriteria yang ingin dicapai' (Atkin, 1973: 206). Dalam paradigma ini, Atkin menjelaskan bahwa konsep intinya adalah ketidakpastian.

Sementara Shannon dan Weaver menyatakan bahwa ketidakpastian dalam 
tingkat yang sederhana akan muncul bila seseorang memandang pengetahuan tentang suatu objek yang dimilikinya diangap tidak lagi memadai. Implikasinya seseorang berusaha untuk memperoleh tambahan informasi guna menutupi kesenjangan pengetahuan. Lebih jauh lagi Atkin mengemukakan bahwa ketidak pastian kognisi yang dimiliki seseorang dirasa tidak memadai lagi untuk merespon situasi yang memerlukan orientasi keputusan atau tindakan yang melibatkan suatu objek atau lebih (Atkin, 1973: 207).

Kebutuhan informasi diperoleh dari pengertian bahwa media bertujuan untuk memenuhi kebutuhan karyawan atas informasi perusahaan. Pengetahuan mengenai karakteristik kebutuhan karyawan dapat menolong pihak manajemen perusahaan untuk menumbuhkan pengertian terhadap para karyawan yang menjadi bagian dari kinerja perusahaan. Selain itu, dapat dijadikan sebagai acuan dalam mencapai pemenuhan kebutuhan karyawan oleh perusahaan, juga membantu karyawan untuk menyadari bentuk-bentuk kebutuhan yang dapat dipenuhi oleh perusahaan. Untuk memenuhi kebutuhan informasi karyawan tersebut maka harus ada komunikasi internal, komunikasi internal adalah komunikasi yang dikirimkan kepada anggota dalam suatu organisasi (Muhammad, 1995: 97).

Sementara itu, studi ini digambarkan sebagai a dramatic break with effects traditions of the past yaitu suatu loncatan dramatis dari model jarum Hipodermik. Model ini tidak tertarik pada apa yang dilakukan media terhadap khalayaknya tetapi lebih tertarik pada apa yang dilakukan khalayak terhadap media. Katz mengatakan bahwa penelitiannya diarahkan kepada jawaban terhadap pertanyaan 'Apa yang dilakukan media untuk khalayak? (What do the media do to people? )' (Rakhmat, 2003: 65).

Model uses and gratifications menunjukkan bahwa apa yang menjadi permasalahan utama bukanlah bagaimana media mengubah sikap dan perilaku khalayak, tetapi bagaimana media memenuhi kebutuhan pribadi dan sosial khalayak. Khalayak dianggap secara aktif dengan sengaja menggunakan media untuk memenuhi kebutuhannya dan mempunyai tujuan. Studi dalam bidang ini memusatkan perhatian pada penggunaan (uses) isi media untuk mendapatkan kepuasan (gratifications) atas pemenuhan kebutuhan seseorang. Dari sinilah timbul istilah uses and gratifications (penggunaan dan pemenuhan kebutuhan). Sebagian perilaku khalayak akan dijelaskan melalui berbagai kebutuhan (needs) dan kepentingan individu (Ardianto dan Erdinaya, 2004:71). Dengan demikian, kebutuhan individu merupakan titik awal dari kemunculan teori ini.

Teori uses and gratifications dimulai di lingkungan sosial dimana yang dilihat adalah kebutuhan dari para khalayak. Lingkungan sosial meliputi ciri-ciri afiliasi kelompok dan ciri-ciri kepribadian. Kebutuhan individual di kategorisasikan sebagai berikut: (1) Cognitive Needs (Kebutuhan Kognitif), yaitu kebutuhan yang berkaitan dengan peneguhan informasi, pengetahuan dan pemahaman mengenai lingkungan. Kebutuhan ini didasarkan pada hasrat untuk memahami dan menguasai lingkungan, juga memuaskan rasa penasaran dan dorongan untuk penyelidikan. (2) Affective Needs (Kebutuhan Afektif) yaitu kebutuhan yang berkaitan dengan peneguhan pengalamanpengalaman yang estetis, menyenangkan dan emosional. (3) Personal Integrative needs (Kebutuhan Pribadi secara Integratif), yaitu kebutuhan yang berkaitan dengan peneguhan kredibilitas, kepercayaan, stabilitas dan status individual. Hal-hal tersebut diperoleh dari hasrat akan harga diri. (4) Sosial Integrative Needs (Kebutuhan Sosial secara Integratif), yaitu kebutuhan yang berkaitan dengan peneguhan kontak dengan keluarga, teman dan dunia. Hal-hal 
tersebut didasarkan pada hasrat untuk berafiliasi. (5) Escapist Needs (Kebutuhan Pelepasan), yaitu kebutuhan yang berkaitan dengan hasrat ingin melarikan diri dari kenyataan, kelepasan emosi, ketegangan dan kebutuhan akan hiburan.

Berdasarkan uraian diatas jelas bahwa dalam menggunakan suatu media, seseorang didorong oleh motif-motif tertentu. Ada berbagai kebutuhan yang dapat terpuaskan dengan menggunakan media massa, namun pada saat yang sama kebutuhan ini juga dapat terpuaskan oleh sumber-sumber lainnya. Contohnya, kebutuhan akan informasi dan hiburan dapat diperoleh dari sumber-sumber lainnya, seperti keluarga, tetangga, dan teman melalui interaksi sosial. Interaksi sosial merupakan kunci dari kehidupan sosial. Karena dengan adanya proses interaksi, manusia bisa berhubungan dengan yang lainnya dan tidak terisolasi. Dalam proses inilah terjadi hubungan timbal balik antara individu dengan individu, individu dengan kelompok ataupun kelompok dengan kelompok lainnya. Sesuatu yang tidak lepas dari interaksi adalah kontak sosial dan komunikasi. Dengan adanya kontak sosial dan komunikasi, orang dapat saling mempengaruhi dan bertukar informasi.

Interaksi yang dilakukan oleh karyawan PT. Telkom DCS Semarang untuk memenuhi kebutuhan informasi akan perusahaan adalah interaksi pada lingkungan kerja. Menurut Nitisemo (1996: 109), lingkungan kerja merupakan segala sesuatu yang ada disekitar karyawan dan dapat mempengaruhi karyawan dalam menjalankan tugas-tugas yang dibebankan. Pernyataan diatas juga didukung oleh pendapat Ahmadi (2002: 77), lingkungan kerja dinyatakan sebagai kehidupan sosial, psikologi dan fisik dalam organisasi yang berpengaruh terhadap karyawan dalam melaksanakan tugasnya.

$\begin{array}{rrr}\text { Penelitian ini sendiri menelaah } & \text { aktivitas }\end{array}$

penggunaan portal Telkom sebagai media internal perusahaan terhadap pemenuhan kebutuhan informasi karyawan. Penelitianinimenggunakan lebih dari dua variabel atau korelasi ganda (multiple correlation), yaitu variabel independent (Aktivitas Penggunaan Portal Telkom (X1)), variabel dependent (Pemenuhan Kebutuhan Informasi Karyawan (Y)) serta variabel kontrol (Interaksi Sosial (X2)) yang juga dapat mempengaruhi pemenuhan kebutuhan informasi karyawan tentang perusahaan.

\section{Penutup}

Hasil uji statistik hubungan antara aktivitas penggunaan portal Telkom (X1) dengan pemenuhan kebutuhan informasi karyawan (Y) menunjukkan nilai korelasi (rs) dalam penelitian ini adalah sebesar 0,62 hal ini menunjukkan ada hubungan yang positif antara aktivitas penggunaan portal Telkom sebagai Media Internal Perusahaan dengan kebutuhan informasi karyawan PT. Telkom DCS Semarang dengan tingkat korelasi yang kuat. Sementara itu, hasil uji statistik hubungan antara interaksi sosial (X2) dengan pemenuhan kebutuhan informasi karyawan (Y) menunjukkan nilai sebesar 0,57 hal ini menunjukkan ada hubungan yang positif antara proses interaksi di lingkungan kerja dengan kebutuhan informasi karyawan PT. Telkom DCS Semarang dengan tingkat korelasi yang kuat.

$\begin{array}{cccc}\text { Untuk } & \text { beberapa } & \text { saran } & \text { yang } \\ \text { ditawarkan } & \text { peneliti, } & \text { yakni: } & \text { bagi }\end{array}$
perusahaan atau lembaga, antara lain: (1) terus meningkatkan pembaharuan (update) berita secara keseluruhan, mulai dari lingkupkantor pusat hingga kantor cabang sehingga seluruh informasi mengenai perusahaan dapat diketahui oleh seluruh karyawan; (2) sebaiknya web portal Telkom memperbanyak berita-berita ringan ataupun info hiburan agar karyawan tidak jenuh melihat tampilan isi portal Telkom yang dipenuhi dengan berita seputar perusahaan; (3) pada web portal 
Telkom disediakan kolom khusus penyampaikan kritik dan saran tentang sehingga karyawan dapat memberikan masukan-masukan ide ataupun informasi untuk pengembangan portal Telkom yang lebih baik lagi.

\section{Daftar Pustaka}

Ahmadi, H. A. (2002). Psikologi Sosial. Jakarta: Rineka Cipta

Ardianto, E., \& Erdinaya, L. K. (2004). Komunikasi Massa Suatu Pengantar. Bandung : PT. Remaja Rosdakarya

Atkin, C. (1973). Instrumental Utilities and Information Seeking. In Clarke, Peter (ed). New Model for Mass Communication Research. Beverly Hills: Sage.

Effendi, O. U. (2002). Dinamika Komunikasi. Bandung: PT. Remaja Rosdakarya.

Laudon, K. C. (2005). Sistem Informasi Manajemen. Yogyakarta: Andi.
Nitisemito, A. S. (1996). Manajemen Personalia: Manajemen Sumber Daya Manusia. Jakarta: Ghalia Indonesia.

Muhammad, A. (1995). Komunikasi Organisasi. Bandung: PT Remaja Rosda Karya.

Pace, R. W. \& Faules, D. F. (2000). Komunikasi Organisasi, Meningkatkan Kinerja Perusahaan. Bandung: PT Remaja Rosdakarya.

Rakhmat, J. (2003). Psikologi Komunikasi. Bandung: PT. Remaja Rosdakarya.

Sugiyono. (2009). Memahami Penelitian Kualitatif. Bandung: Alfabeta.

Suranto, A. W. (2005). Komunikasi Perkantoran. Yogyakarta: Media Wacana.

Sutedjo, B. D. O. (2003). Terminologi Populer Sistem Informasi. Yogyakarta: Graha Ilmu.

Tung, K. Y. (2001). Teknologi Jaringan Intranet. Yogyakarta: Andi. 